\title{
ICD 管理業務と臨床工学技士の役割
}

齊藤 建 山崎隆文 大石杏衣 熊井良一 鈴木 誠

【要旨】高度医療の発展に伴い, 植込み型除細動器 (ICD) 植込み患者数も増加傾向にある。そのよ うな状況の中で, ICD の専門性を考慮すると患者の管理体制の整備は重要である。当院では 2001 年 より我々臨床工学技士 (CE) が医師の指示の下 ICD 管理業務を行っている。業務内容は植込み前に 行われる心臓電気生理学的検査, 植込み手術, 定期 ICD 外来, 臨時点検, 患者管理などである。点 検件数は増加傾向であり, 頻脈に関する設定変更は定期点検 6 件 (4.8\%), 臨時点検 13 件 (27.7\%) であった $(\mathrm{p}<0.001)$ 。このこから臨時点検での対応が重要であることが考えられ, 特に誤作動発 生時などでは迅速な対応が患者の QOL を向上させる。CE が ICD 管理業務を行うことにより安全 かつ効率的な管理体制が整った。

Key words : 臨床工学技士, ICD

\section{I .はじめに}

近年，不整脈や心不全に対する内科的治療はます ます高度に発展してきている1。 その中で植込み型 除細動器 (以下, ICD) は特に心臓突然死の原因とな る致死性不整脈の治療に有効であり，その専門性を 考慮すると患者の管理体制の整備は重要である。

最近ペースメーカー業務は臨床工学技士（以下, CE）の業務として徐々に漫透しつつあるが2)，ICD 業務はまだ確立されていないのが現状である。

当院では 2001 年より我々 CE が ICD 業務全般に 携わっており，効率的な管理体制が整った。今回当 院の管理体制と CE の役割について報告する。

\section{II. 対象および方法}

2001 年から 2004 年 12 月までに当院で ICD を植 込んだ患者 16 例（男性 8 例，女性 8 例）を対象とし た。基礎疾患は虚血性心疾患 8 例, 特発性心室細動 3 例, 心筋症 3 例, Brugada 症候群 1 例, 心サルコ イドーシス 1 例であった。使用機器は Single Chamber 6 例, Dual Chamber 10 例であった。

I. CE のICD 業務（図 I）

1) 植込み前の電気生理学的検査（以下，EPS)

不整脈の誘発や解析を行うために, 刺激解析装 置の操作を行う。

2 ) 植込み手術

本体の設定, 電池電圧, 刺激間値, 心内電位, 抵抗值, 除細動閥值などの測定を行う。また物品 管理, ICD 手帳, トラッキング用紙記入などの事

- 田総合病院 ME 室

1) 同循㻴器内科
務的業務も行う。

3 ) 退院前点検

当院では植込み一週間後を退院の目安としてい るが，その前に再度点検を施行している。このと き胸部 X 線写真も観察し特にリードの移動に注 意する。

4) ICD 外来点検

年 4 回 $\mathrm{ICD}$ 外来を設けている。その際 $\mathrm{CE}$ が胸 部 X 線写真と心電図を確認後点検, イベントの解 析, ICD 手帳・管理表へのデータ記入をしてい る。

5 ) 臨時（院内・外来依頼, 手術時, 緊急など） 点検

循環器内科一般外来での点検依頼や救急外来な どでの依頼も引き受け対応を行っている。

デー夕管理の方法はまず患者一人一人にペーパ 一の管理表を作成する。これを植込み手術や各点 検の際に携帯し点検の結果, イベントの有無, 設

-電気生理学的検查(VT Study)

・ICD植込み手術

電池電圧、刺激闢値、心内電位、抵抗值等の測定 DFT測定、解析 ICDの設定

$\underset{\text { ICD手帳作成、トラッキング用紙作成、管理表作成 }}{\text { ·退院前点検 }}$
·定期ICD外来
·臨時点検
·患者テータ管理

図 ICE のICD 業務 
定変更などを記入する。そしてパソコン上にも同 様の管理ファイルを作成し点検結果を入力してい る(図 2,3 )。今回, これらのデータを集計し た。

\section{III. 結 果}

\section{1. 点榙の状況}

2001 年から 2004 年まての定期 ICD 外来（以下, 定期)の総件数は 126 件であった。内訳は 2001 年 10 件, 2002 年 27 件, 2003 年 40 件, 2004 年 49 件であ った。定期以外の臨時点模（以下, 臨時）は 67 件 て, 内訳は 2001 年 0 件, 2002 年 11 件, 2003 年 15 件, 2004 年 21 件であった。

その中で設定変更は定期 26 件 (20.7\%), 臨時 19 件 $(40.5 \%)$ 。頻脈以外の変更は定期 20 件 (15.9 $\%)$, 蹋時 6 件 (12.8\%)。頻脈に関する変更は定期 6 件 (4.8\%), 臨時 13 件 (27.7\%) であった（p< 0.001)（図 4)。

\section{CEによる対処が有効であった事例}

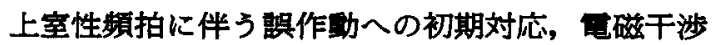
による奜作動への対応, 外科手術時の対応, リード 断線の早期発見, 各種検查 (CT, MRI など)におけ る問い合わせへの対応などが挙げられ迅速に対応し た。

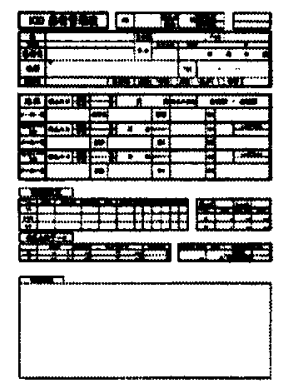

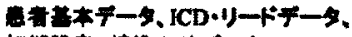

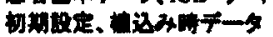

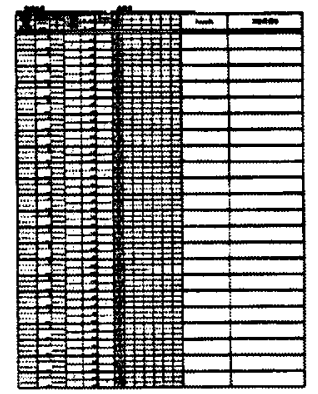

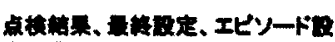
这校要
図 2 息者管理表

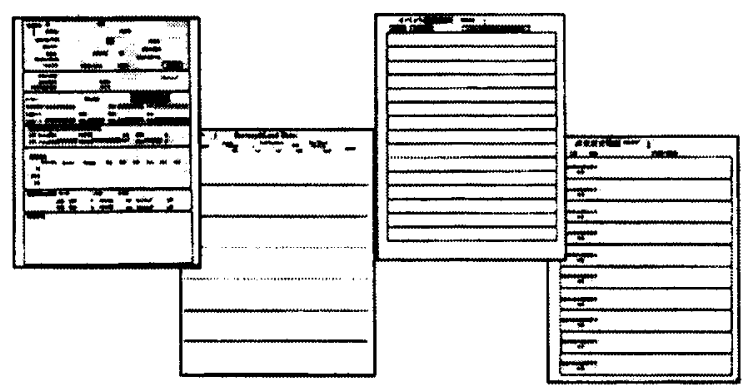

ต* (x)

図 3 PC での管理衰
IV. 考 察

ICD 患者管理を CE が行うことによる最大のメリ ットとして結果でも示したが，迅速な初期対応が可 能になるということである(図 5 )。絮急を要する点 模（棓作動や頻回作動例いわゆる Electrical Storm など）はさほど多くはないが，その場合の早期対応 つまりデータを詠み出しイベントを解析したり，設 定変更をしたりすることは患者のQOL を考虔する と非常に重要である。

また，社会的背景（仕事や家庭環境）を含めた患 者データを院内で一括管理することて，各種測定値， イベント履歴，設定変更履歴が容易に把哄でき次回 以降の点検にフィードバックすることができる。

ICDのガイドラインが整備され今後棺込み患者 が更に増加する可能性もあり ${ }^{1,3,4}$ 患者管理の重要性 も增してくると考えられる。ICD 管理は尃門的な知 識を必要としメーカーに依存する部分も少なくない か，本来ならば医療機関に所属する有资格者が取り 扱うことが理想であり，このことから我々CEが適 任であると考える。

ICD を扱う施設において CE が䅡極的に業務に関 与していくことで，患者の $\mathrm{QOL}$ をより向上させ効

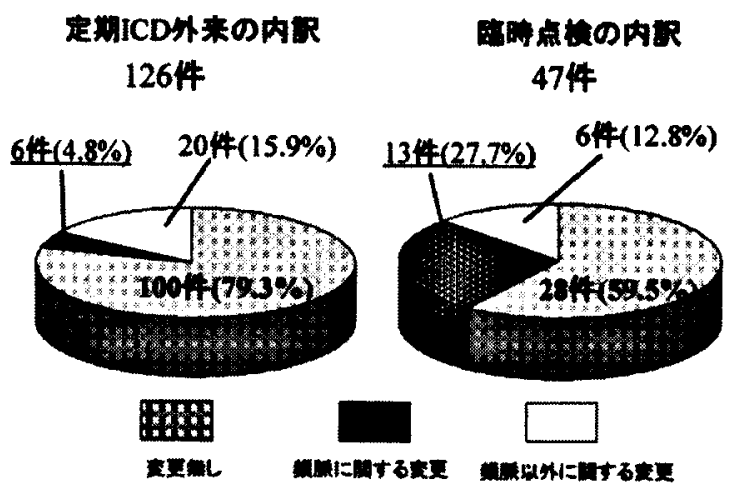

图 4 点検件数の内訳

メリット1. 登魚時の対底

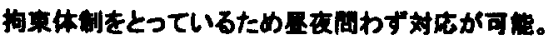

メリット2. データ管理の一元化 ICD惫のデータは全てMEが管理しているので、

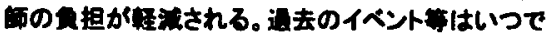
も格需が可能。

メリット3. 手得䀠の対㡾

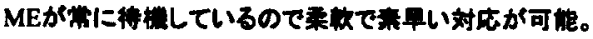
•效事的な策理体制 •舟者のQOLの向上

図 5 CEが管理することによるメリット 
率的な管理体制が実現すると考える。

V. まとめ

臨床工学技士が ICD 管理に積極的に関与するこ とで, 安全で効率的な管理体制が整った。

- 参考文献

1) 石川利之：心臓ペーシングのすべて. 初版, 東京, 中外医学社. 2004. p.169-231.

2 ) 大岩成明, 中嶋浩詞, 山本裕隆：当院の植え込み型
ペースメーカー外来業務について. 日本臨床工学技士 会会誌, $22 ； 24-25,2005$.

3 ）樋熊拓未, 佐々木真吾, 奥村 謙: 適応と予後改善 効果. 治療学, 37(7)；31-36, 2003.

4 ）副島京子, Julie B.Shea,RN：内科医による ICD 植 込み. 治療学, $37(7) ； 37-38,2003$.

〔本論文は, 第 31 回日本体外循環技術研究会大会にて 